dam would destroy the Mau forest, and this would further decrease the Mara River dry season flows (Mango et al., 2011, Hydrology and Earth System Sciences, 15, 2245-2258). (8) During the dry season in a drought year there would be zero MEF for the Masarua swamp. (9) Seventy-five percent of the world's lesser flamingos are born around Lake Natron. The diversion of Mara River water to the lake will flood their nesting sites.

If the wildebeests cannot use the Mara River (their only water resource in the dry season in a drought year), modelling studies suggest that $80 \%$ may die (Gereta et al., 2009, Ecohydrology \& Hydrobiology, 9, 115-124), leaving behind a much-impoverished ecosystem. To save the Serengeti ecosystem an international effort is needed to enable Tanzania to be involved as an equal partner with Kenya in the decision-making about managing the Mara and Ewaso Ngiro Rivers and, if that is not possible, to prevent the financing of these dams.

BaKari MNAYA Tanzania National Parks, Arusha, Tanzania E-mail bakari.mnaya@tanzaniaparks.go.tz

Mtango G.G. Mтанiкo Tanzania National Parks, Arusha, Tanzania.E-mail mtango.mtahiko@tanzaniaparks.go.tz

ERIC WolansKI James Cook University, Townsville, Australia E-mail eric.wolanski@jcu.edu.au

\section{Hunting for the wealthiest threatens migrating cranes in Afghanistan}

Hunting during migration is a significant threat to birds relying on the Central Asian flyway for their journeys between wintering and breeding grounds. Cranes in particular suffer losses when passing across certain areas of Pakistan and Afghanistan, where hunting them for sport is a traditional pastime. The loss of adult and young birds during migration through these areas is thought to have been the leading factor behind the decline and extinction of the Central Asian population of Siberian cranes Leucogeranus leucogeranus. Although crane hunting and offtake levels have been studied in Pakistan, very little is known about crane hunting in Afghanistan.

The National Environmental Protection Agency and the Wildlife Conservation Society carried out a joint assessment of crane hunting in Kapisa and Parwan provinces of Afghanistan in April 2015, 2016 and 2017. The surveys concluded that the demoiselle crane Anthropoides virgo and Eurasian crane Grus grus are the main objects of hunting activity between the last week of March and mid April, but many species of waterfowl and waders are also taken, such as 120 pelicans (Pelecanus spp.) in spring 2017. Nowadays hunters no longer use traditional methods such as sling-propelled rocks, and use firearms only. They shoot cranes opportunistically or after luring them with tame cranes, or sometimes after netting them. In contrast to what has been described in Pakistan the vast majority of cranes currently taken in Afghanistan are hunted for meat, a few for the pet trade, and some to be used as lures to attract conspecifics. Most of the cranes are taken in spring and only a few in autumn, which is the high season for black-bellied sandgrouse Pterocles orientalis and lark (Melanocorypha spp.) harvesting. Numbers of harvested cranes in spring may vary between years. In Barik Aab, Parwan Province, known to be a hotspot for crane hunting, we estimated that 15-20 hunting camps harvested 1,6002,000 cranes during spring 2015, but less than half that level in 2016 and even fewer in 2017 because, according to hunters, good weather conditions allowed birds to pass the Hindu Kush without stopping. However, even in 2017 the 16 hunting camps operating in the area succeeded in capturing 200-300 cranes for the pet trade.

Crane hunting is a lucrative activity. A crane is sold for meat for USD 30-40, a much higher price than mutton/beef meat (USD $5-7 \mathrm{~kg}^{-1}$ ) because of its alleged aphrodisiac properties. A live couple of demoiselle cranes can fetch USD 2,500 and a couple of Eurasian cranes up to USD 4,000 , prices that only the wealthiest can afford. This hunting is so profitable that it brings hunters into fierce competition, and in the last few years it is alleged that at least seven have died in hunting disputes. The modernization of hunting techniques, weakening of cultural traditions of restraint, and attractiveness of high profits raise concerns that kill rates of cranes in Afghanistan no longer remain below the recruitment rate and may jeopardize the survival of populations migrating through the country.

In spite of the formal opposition of the National Environmental Protection Agency to the hunting or capture of protected bird species, people continue to hunt all species of birds, and merchants to buy and sell them for meat or the pet trade. Curbing illegal bird hunting in Kapisa and Parwan provinces is a challenging task because of insufficient support from law enforcement authorities, the widespread availability of firearms and ammunition, and the growing demand for crane meat and pet birds from wealthy customers. In general the impact of subsistence hunting is likely to become increasingly acute as human populations grow and habitat continues to be lost. However, in the case of cranes in Afghanistan the demand comes mainly from wealthy customers who do not consume the meat for subsistence. In such circumstances a determined government commitment against a handful of powerful people generating the demand and sometimes organizing the supply chain, listing the Eurasian and demoiselle cranes as legally protected, implementing public awareness campaigns, and educating the wealthiest could prove efficient actions to decrease hunting pressure on cranes and other migratory bird species in Afghanistan. 
Sayed Naqibullah Mostafawi Wildlife Conservation Society, Afghanistan Program, Kabul, Afghanistan

JALALUDIN NASERI National Environmental Protection Agency, Kabul, Afghanistan

Stephane Ostrowski Wildlife Conservation Society, Afghanistan Program, Kabul, Afghanistan

E-mailsostrowski@wcs.org

\section{Urgent conservation of Buchanania barberi (Anacardiaceae) in Kerala, India}

The evergreen tree Buchanania barberi Gamble of the family Anacardiaceae is endemic to the South Western Ghats of Kerala, India. The first herbarium specimen of the species was collected in Nadarai, Thiruvananthapuram, in 1904 by C.A. Barber and the species was described by J.S. Gamble in 1916 (J.S. Gamble, 1916, Notes of the Flora of Madras. Kew Bulletin, 135). The species was categorized as Endangered in the Red Data Book of Indian Plants in 1990 and as Critically Endangered on the IUCN Red list in 1998. The species was rediscovered by staff of the Jawaharlal Nehru Tropical Botanic Garden and Research Institute (JNTBGRI) in the Palode region of Thiruvananthapuram in 2001 (Santhosh Kumar et al., 2002, Rheedea, 12, 197200). In 2005 the species was included in the national priority list of endangered plants.

In 2016 Botanic Gardens Conservation International, UK, made a grant to JNTBGRI to support research on this species. A total of 11 field surveys were carried out in the Palode region (c. $74 \mathrm{~m}$ altitude) from July 2016 to June 2017. Four individuals were recorded, of which two were adult and two were juvenile trees. The area of occupancy of the species is $<5 \mathrm{~km}^{2}$. This species has no clonal growth and propagates by seeds. Our surveys and information obtained from interviews with local people reveal: (1) low fruit production despite high levels of flowering (2) no record of establishment of seedlings, (3) consumption of the fruits by birds, (4) low seed germination as a result of dormancy and unfavourable conditions, and (5) the impact of development programmes in the area, especially road expansion.

Our research on seed collected in April 2017 indicates delayed germination with dormancy. Experimentation with methods to break dormancy and establish seedlings are being carried out. Further research and surveys are required in South Kerala, with the help of local forest range officers and taxonomists, to elucidate fully the conservation status of this rare and Critically Endangered species.

We acknowledge support from Botanic Gardens Conservation International, UK (grant no. A217).

Anurag Dhyani and C. Anilkumar Division of Conservation Biology, Jawaharlal Nehru Tropical Botanic Garden and
Research Institute, Thiruvananthapuram, Kerala, India E-mail anuragdhyani@gmail.com

\section{Missing monkey found: Vanzolini's bald-faced saki monkey Pithecia vanzolinii}

A recent revision of the taxonomy of the Neotropical saki monkeys (genus Pithecia) described a total of 16 species, including five new species (Marsh, L.K., 2014, Neotropical Primates, 21, 1-165). In the revision the only information on $P$. vanzolinii came from museum specimens, and it was the only saki for which there was no photographic evidence of living individuals. The holotype was collected by A.M. Olalla in 1936 in the Lago Grande region, south of the Rio Juru and west of the Rio Eiru in Amazonas state, Brazil, and until this reporting went undocumented there for nearly 80 years. Pithecia vanzolinii is currently categorized as Data Deficient on the IUCN Red List.

In January-February 2017 an expedition called Houseboat Amazon, co-organized by Global Conservation Institute, USA, and Mamirauá Sustainable Development Institute, Brazil, surveyed for large mammals, with a particular focus on primates, along the Rio Eiru and Igarapé Preto in Amazonas. We searched for P. vanzolinii in the location where it was originally collected, with the goal of determining its existence and to record behavioural, demographic, distribution, and habitat information for the species. The full scope of the project (January-May 2017) included assessment of hunting and fishing, habitat analysis, drone mapping, and photography of all encountered species in the major watersheds on the right bank of the Rio Jurua: Tarauacá, Eiru, Gregório, and Riozinho da Liberdade.

The region has three distinct forest types: várzea (seasonally whitewater-flooded), igapó (seasonally blackwater-flooded), and terra firme (forest that does not flood seasonally). Surveys were conducted on foot in terra firme, by small, motorized canoes in rivers and lakes, and by twoperson canoes in várzea and igapó. Local guides were employed to perform surveys with the research team. In January a two-person team conducted 10 surveys along Igarapé Preto (a total of 64 hours and $28 \mathrm{~km}$ ). In February a total of 35 surveys were conducted along the Rio Eiru by 68 investigators in 3-4 teams per day (a total 208 surveyhours and 240 survey-km).

Pithecia vanzolinii was observed in both flooded and unflooded forest, in multiple locations on both sides of the Rio Eiru, from the mouth of the Rio Jurua $40 \mathrm{~km}$ upriver to the border of the Terra Indígena Rio Eiru. We observed the species in the original collection locations: one sighting in the igapó of Lago Grande, three sightings in igapó and terra firme near Santo Antônio, and near the former village of Santa Cruz, with one sighting in the Lago Paris area. In Igarapé Preto and its contiguous igapó, we sighted the 